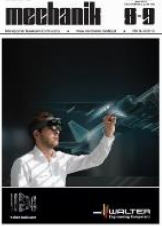

Authors: Michał Ociepa, Mariusz Jenek, Maria Zhbankova

Title of article: „Analiza wpływu powłok przeciwzużyciowych na ostrzach skrawających na stan warstwy wierzchniej po toczeniu wykończeniowym stali C45" ("Analysis of the influence of antiwear coatings on cutting tools on the condition of the surface layer after finishing turning of C45 steel")

\title{
Analysis of the influence of antiwear coatings on cutting tools on the condition of the surface layer after finishing turning of C45 steel
}

\author{
Analiza wpływu powłok przeciwzużyciowych na ostrzach skrawających \\ na stan warstwy wierzchniej po toczeniu wykończeniowym stali C45
}

\author{
MICHAt OCIEPA \\ MARIUSZ JENEK \\ MARIA ZHBANKOVA *
}

The results of research on the influence of multi-layer CVD and PVD coatings on carbide cutting tools on selected parameters of the surface layer after finishing turning of C45 steel (1.0503) are described. The research showed a significant effect of antiwear coatings on the condition of surface layer. In the case of all tested blades, an increase in the strengthening level of the surface layer was noted along with the increase of the feed rate.

KEYWORDS: wear-resistant coatings, PVD, CVD, finish turning, surface layer

The state of the surface layer (SL) of the machine elements results mainly from the technology of their execution and should take into account the working conditions of these elements. In connection with this SL, certain mechanical, physical and chemical properties are suitable [1]. Roughness and micro-surface area are considered as an indicator of product quality, and achieving the desired surface roughness is crucial for its functionality [2].

In terms of operational properties, the roughness parameters characterize primarily the thermal conductivity of a given element and its resistance to abrasion, fatigue and corrosion. In the case of high uneven surfaces, the uneven tops touch each other, resulting in increased abrasive wear and, over time, the appearance of adhesive wear [3].

Technical progress and the need to increase the productivity and reliability of machining processes lead to the implementation of increasingly advanced tool materials and anti-wear coatings. They allow to optimize the cost of production of machine elements and at the same time to increase the machining efficiency [4]. Currently, over $90 \%$ of manufactured carbide cutting blades have anti-wear coatings applied by PVD, CVD or their combinations [5].

\footnotetext{
* Mgr inż. Michał Ociepa (m.ociepa@ibem.uz.zgora.pl), dr hab. inż. Mariusz Jenek prof. UZ (m.jenek@ibem.uz.zgora.pl) - Wydział Mechaniczny Uniwersytetu Zielonogórskiego; inż. Maria Zhbankova (zhbankova.masha2011@yandex.ru) - Instytut Budowy Maszyn Moskiewskiego Państwowego Uniwersytetu Technologicznego „Stankin”
}

According to [6], the thickness, thermal properties, residual stresses and adhesion are different for CVD and PVD coatings, which results directly from the technology of their application to cutting tools.

PVD coatings, compared to CVD, are more resistant to wear due to their high hardness. They are also characterized by compressive stresses, which ensure higher strength of the cutting edge and extend the overall reliability of the tool $[6,7]$.

Although anti-wear coatings on cutting blades have been used in the machine industry for more than 40 years and many tests have been carried out in this area, there are still issues requiring further analysis.

One of them is to study the properties and impact of PVC and CVD multi-layer coatings on the cutting process [8].

The aim of this work was a comparative analysis of the influence of multi-layer PVD and CVD anti-wear coatings applied by manufacturers on cutting blades for selected roughness parameters, depth and reinforcement degree SL after the C45 steel finishing process.

\section{Test conditions}

For the tests, qualitative non-alloy steel C45 (AISI 1045) was used in the initial state, whose chemical composition is shown in the table I [9].

TABLE I. Chemical composition of C45 steel (AISI 1045), \% by weight

\begin{tabular}{|c|c|c|c|c|}
\hline $\mathrm{C}$ & $\mathrm{Mn}$ & $\mathrm{Si}$ & $\mathrm{P}$ & $\mathrm{S}$ \\
\hline 0.42 & 0.72 & 0.19 & 0.04 & 0.02 \\
\hline
\end{tabular}

Feeds were applied in the range of $0.05 \div 0.28 \mathrm{~mm} / \mathrm{rev}$, constant cutting speed of $150 \mathrm{~m} / \mathrm{min}$ and constant depth of cut of $0.25 \mathrm{~mm}$, which corresponds to the finishing conditions.

Turning was carried out with a knife with CSDPR 2020K12 holder with the following cutter geometry: entering angle $K_{r}=45^{\circ}$, angle of attack $\gamma=5^{\circ}$, clearance angle $\alpha=6^{\circ}$, corner radius $r_{\varepsilon}=0.8 \mathrm{~mm}$. SPUN 120308 carbide replacement plates were used, the characteristics of which are shown in the tab. II. 
TABLE II. Characteristics of cutting blades used in tests

\begin{tabular}{|l|c|c|c|}
\hline $\begin{array}{l}\text { Symbol } \\
\text { of the tile }\end{array}$ & HW (SM25) & PVD 3W & CVD 3W \\
\hline Coating & - & $\begin{array}{c}\text { TiN, (TiAISi)N, } \\
\text { TiN }\end{array}$ & $\begin{array}{c}\mathrm{TiN} \mathrm{Al}_{2} \mathrm{O}_{3}, \\
\mathrm{TiCN}\end{array}$ \\
\hline $\begin{array}{l}\text { Type } \\
\text { of coating }\end{array}$ & - & PVD & CVD \\
\hline
\end{tabular}

Research on selected roughness parameters was carried out on a PMG-1C profilographometer. The study of microhardness, depth and degree of strengthening was carried out radially on a Zwick ZHV 10 durometer with a load of $0.3 \mathrm{~N}$.

\section{Test results of selected roughness parameters}

Figs. 1-3 present values of selected roughness parameters $R a, R z, R S m$ depending on feed speed $f$, for surfaces treated with all tested cutting blades.

The lowest value of all parameters for the entire tested feed range $f$ was recorded for surfaces treated with PVD $3 W$ blades. In relation to the $\mathrm{HW}$ plate (without coating), all parameters were lower by $13 \div 20 \%$.

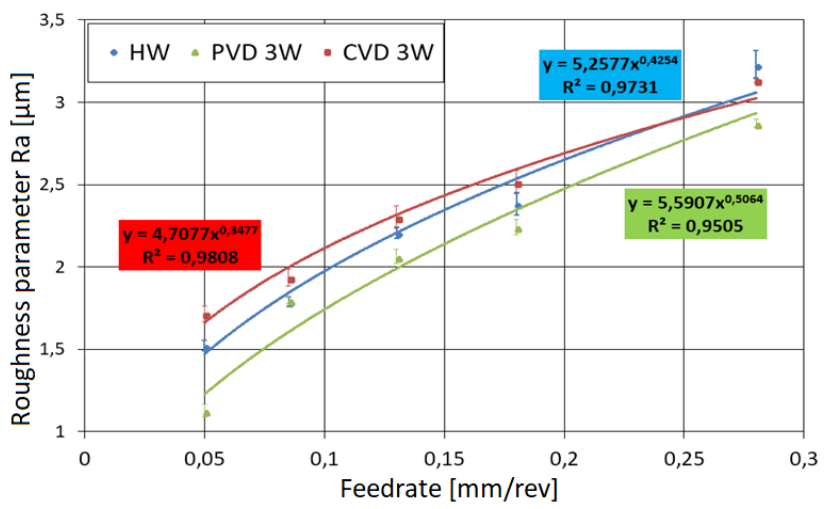

Fig. 1. Results of measurements of the roughness parameter $R a$

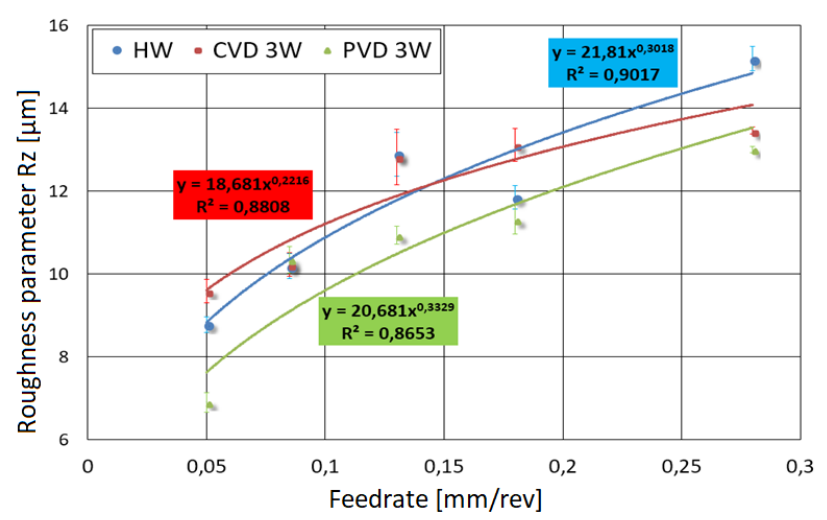

Fig. 2. Results of measurements of the roughness parameter $R z$

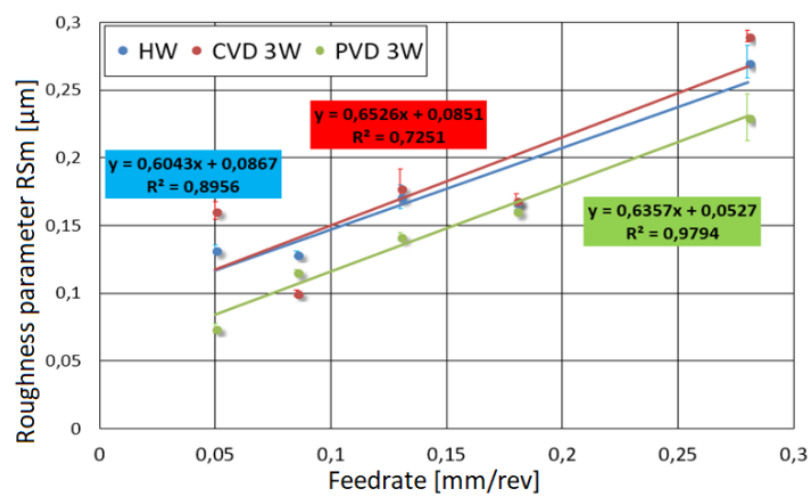

Fig. 3. Results of measurements of the $R S m$ roughness parameter
The values of $R a$ and $R S m$ parameters of surfaces treated with CVD $3 \mathrm{~W}$ and HW blades were similar in the entire range of the tested feed $f$ (fig. 1, fig. 3 ), and the difference between them did not exceed $10 \%$ of the parameter value for the HW blade.

At the feed $f=0.05 \mathrm{~mm} / \mathrm{rev}$, the $R z$ parameter for the HW blade was lower by approx. 6\% compared to the CVD 3W blade. This dependence changed with higher feed values $f$ (from $0.15 \div 0.28 \mathrm{~mm} / \mathrm{rev}$ ) (fig. 2), for which the $R z$ parameter for surfaces treated with a CVD 3W coated blade remained at a constant level. For surfaces machined with $\mathrm{HW}$ blade, it grew, reaching a difference of $\sim 14 \%$.

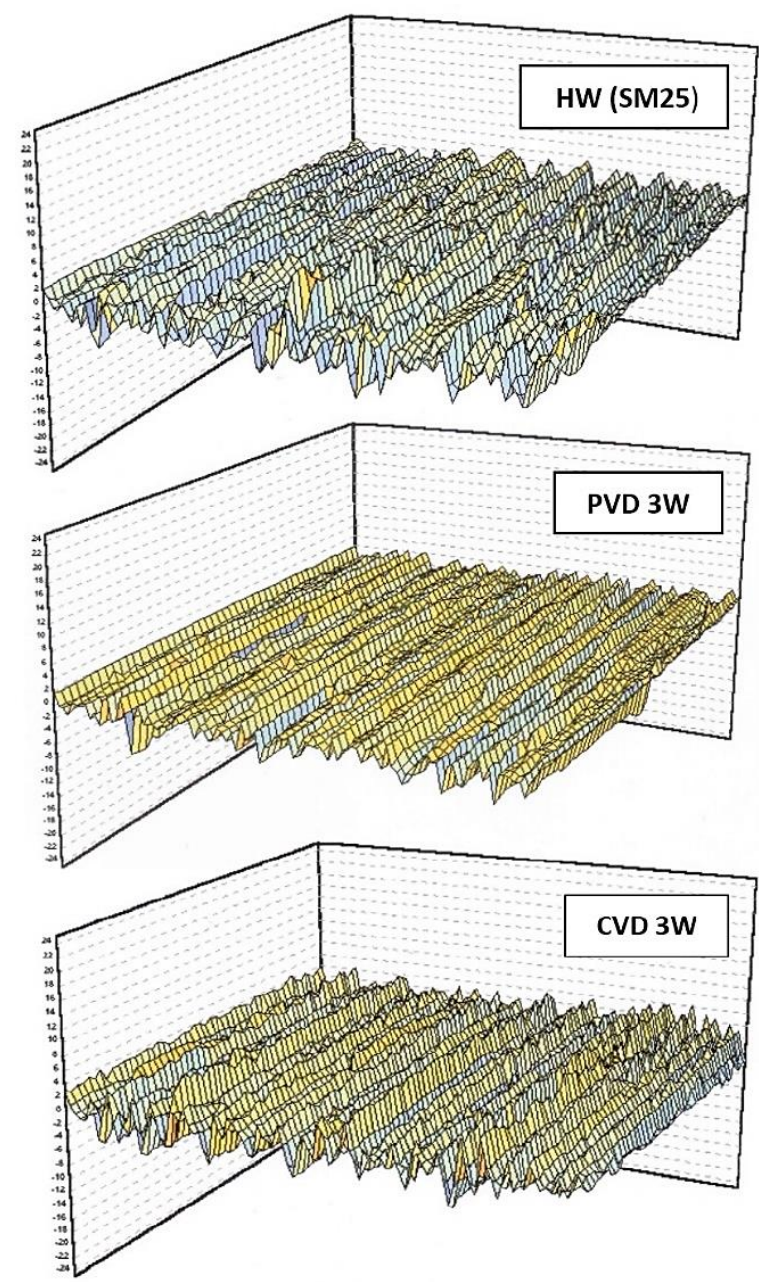

Fig. 4. 3D scans of sample surface samples after cutting with HW, PVD 3W and CVD 3W blades

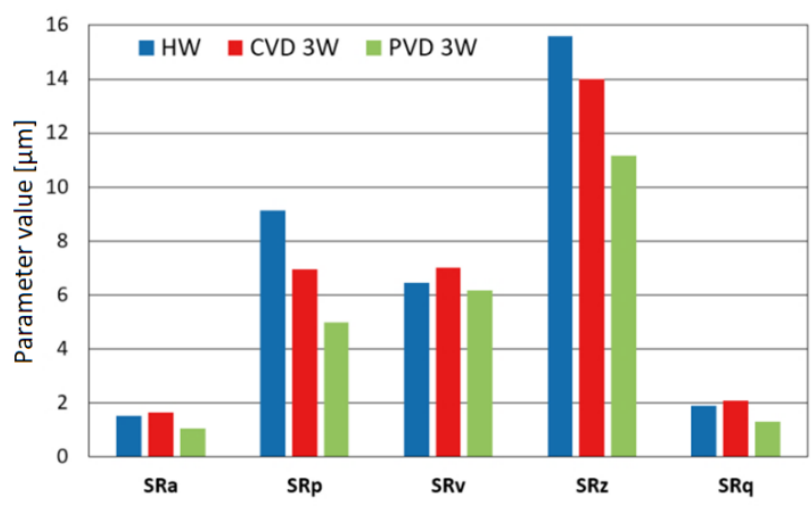

Fig. 5. Example values of 3D roughness parameters

Fig. 4 presents exemplary views of the 3D surface of samples after machining with HW, PVD 3W and CVD 3W blades with a minimum feed value $f=0.05 \mathrm{~mm} / \mathrm{rev}$. Fig. 5 
presents values of selected roughness parameters obtained from 3D measurement, which confirm the previous 2D surface analysis. It can be seen that the surface treated with a PVD 3W blade has the most regular structure.

\section{Results of the research on the degree and depth of strengthening $S L$}

Changes in the strengthening of the SL were determined on the basis of the micro-hardness measurement. The average results of the micro-hardness distribution tests into the depth of the SL in all tested blades after machining with the maximum feed value $(0.28 \mathrm{~mm} / \mathrm{rev})$ are shown in fig. 6 .

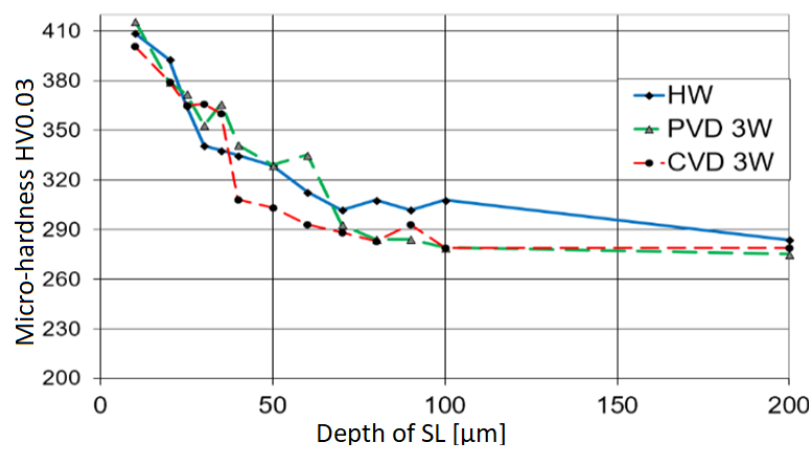

Fig. 6. Distribution of micro-hardness deep into $S L$ after machining with feed $f_{5}=0.28 \mathrm{~mm} / \mathrm{rev}$

On the basis of changes in micro-hardness, the degree and depth of strengthening were determined. The reinforced layer was one whose micro-hardness differed by at least $10 \%$ from the micro-hardness of the core.

Fig. 7 and fig. 8 show the depth and the degree of strengthening SL after turning with tested blades at feed $f_{5}=0,28 \mathrm{~mm} / \mathrm{rev}$.

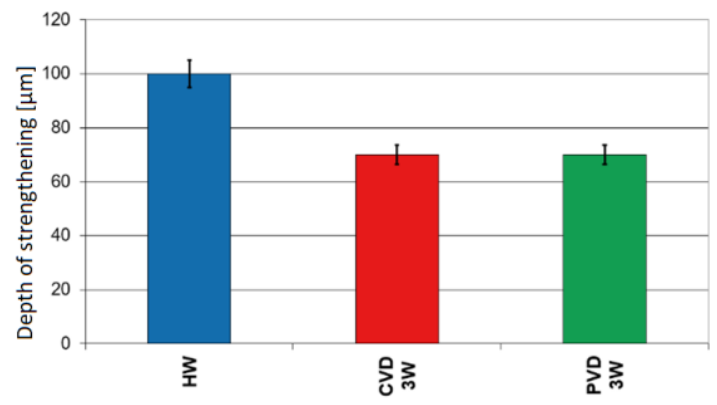

Fig. 7. Results of depth measurement of SL after machining with the feed $f_{5}=0.28 \mathrm{~mm} / \mathrm{rev}$

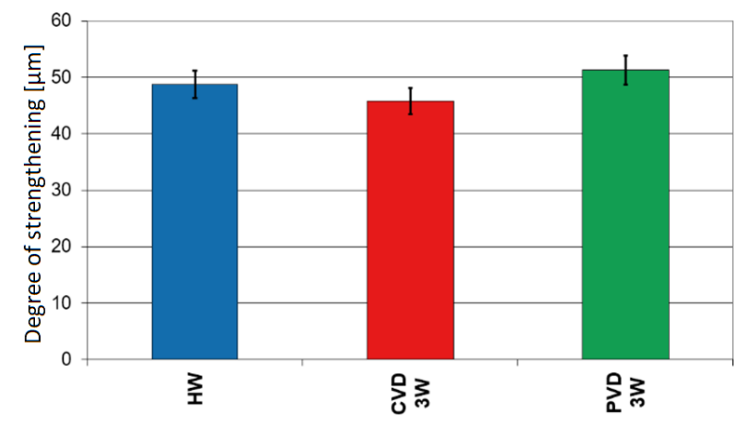

Fig. 8. Results of the measurement of the reinforcement degree SL after machining with feed $f_{5}=0.28 \mathrm{~mm} / \mathrm{rev}$

After taking into account the scatter of results, for the value of force $f=0.28 \mathrm{~mm} / \mathrm{rev}$, no significant differences in the depth and degree of strengthening of SL after machining with blades with CVD 3W and PVD 3W coatings were noticed. The greatest depth of strengthening, greater by approx. $30 \%$ in comparison with the SL after machining of blades with multilayer PVD 3W and CVD 3W coatings, was obtained for the uncoated HW blade (fig. 7).

The test results presented in figs. 7-8 show a lower depth of reinforcement of SL surface treated with coated blades (PVD 3W, CVD 3W) in comparison with surfaces treated with uncoated blades (HW). This was probably due to the interaction of anti-wear coatings with the workpiece.

\section{Conclusions}

The test results allow to draw the following conclusions: - research has shown a significant effect of anti-wear coatings on the condition of SL,

- the smallest value of roughness parameters was obtained for surfaces treated with PVD $3 \mathrm{~W}$ blades with multi-layer coating TiN/(TiAISi)N/TiN applied by PVD technique (reduction of roughness parameters up to $20 \%$ ),

- there were no significant differences in the values of the roughness parameters tested for surfaces treated with $\mathrm{TiN} / \mathrm{Al}_{2} \mathrm{O}_{3} / \mathrm{TiCN}$-coated blades in the $\mathrm{CV}$ technique compared to uncoated blades,

- surface treated with a blade with PVD 3W coating has the most regular geometrical structure,

- presence of the coating significantly affects the degree of plastic deformation in the cutting zone, causing a change in the strengthening depth of SL (up to $30 \%$ ),

- in the case of surfaces treated with coated tools, a lower depth of strengthening SL was achieved.

\section{REFERENCES}

1. Jenek M. Stan warstwy wierzchniej cześci maszyn po skrawaniu ostrzami z powłokami PVD”. Zielona Góra: Oficyna Wydawnicza Uniwersytetu Zielonogórskiego, 2016.

2. Lawate S.K.A., Suryawanshi A.S., Durgavale A.S., Patil S.V. "Experimenta comparison of PVD, CDV and ceramic tool inserts in turning of hardened EN 19/AISI 4140 for optimization of surface roughness and material removal rate". International Advanced Research Journal in Science. Engineering and Technology - National Conference on Design, Manufacturing, Energy \& Thermal Engineering. 4, spec. ed. 1 (2017).

3. Petropoulos G.P., Pandazaras C.N., Davim J.P. "Surface texture characterization and evaluation related to machining". Surface Integrity in Machining (Spring 2010).

4. Bouzakis K., Michailidis N., Skordaris G., Bouzakis E., Biermann D., M'Saoubi R. "Cutting with coated tools: Coating technologies, characterizatizon methods and performance optimization". CIRP Annals Manufacturing Technology. 61, 2 (2012): pp. 703-723.

5. Vereschaka A.A., Grigoriev S.N., Sitnikov N.N., Oganyan G.V., Batako A "Working efficiency of cutting tools with multilayer nanostructured Ti-TiCN(Ti,Al)CN and Ti-TiCN-(Ti,Al,Cr)CN coatings: Analysis of cutting properties, wear mechanism and diffusion processes". Surface and Coatings Technology. 332 (2017): pp. 198-213.

6. Denkena B., Breidenstein B. "Residial stress distribution in PVD-coated carbide cutting tools - origin of cohesive damage". Tribology in Industry. 34, 3 (2012): pp. 158-165

7. Fernandez-Abia A.I., Barreiro J., Fernandez-Larrinoa J., Lopez de Lacalle L.N., Fernandez-Valdivielso A., Pereira O.M. "Behaviour of PVD coatings in the turning of austenitic stainless steels". Procedia Engineering. 63 (2013): pp. 133-141.

8. Inspektor A., Salvador P.A. "Architecture od PVD coatings for metalcutting applications; A review". Surface and Coatings Technology. 257 (2014): pp 138-153.

9. Kimakh K., Chouaf A., Aghzer S., Saoud A., Malil E., Chergui M. "Improvement of fatigue life of AISI 1045 carbon steel of parts obtained by turning process through feed rate". Procedia Structural Integrity. 9 (2018): pp. 243-249.

Translation of scientific articles, their computer composition and publishing them on the website www.mechanik.media.p by original articles in Polish is a task financed from the funds of the Ministry of Science and Higher Education designated for dissemination of science.

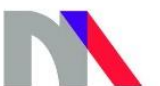

